\title{
Investigation of severe combined immunodeficiency (SCID) disease of Arabian horses raised at the state stud farms in Turkey
}

\author{
Bengi ÇINAR KUL ${ }^{1}$, Özgecan KORKMAZ AĞAOĞLU ${ }^{2}$, Okan ERTUĞRUL ${ }^{1}$, Murat DURMAZ ${ }^{3}$ \\ ${ }^{1}$ Ankara University, Faculty of Veterinary Medicine, Department of Genetics, Ankara; ${ }^{2}$ Mehmet Akif Ersoy University, Faculty of \\ Veterinary Medicine, Department of Animal Science, Burdur; ${ }^{3}$ General Directory of Agricultural Farms (TIGEM), Karacabey \\ Agricultural Farm, Bursa, Turkey.
}

\begin{abstract}
Summary: Severe Combined Immunodeficiency (SCID) is a lethal and autosomal recessive hereditary disorder, which has frequently been reported in Arabian horses, dogs, mice and humans. The genetic basis of equine SCID is 5-base pairs deletion in the DNA-dependent protein kinase catalytic subunit (DNA-PKcs) gene. Up to date, there is no information on the presence of SCID in Arabian horses reared in Turkey either by clinical observation or molecular diagnosis. The main aims of this study were to investigate the presence of SCID mutant allele carrier and to determine SCID incidence in Turkey using molecular techniques. In the study, DNA samples were obtained from 239 Arabian horses raised in state stud farms of Turkey (Karacabey, $\mathrm{n}=70 ;$ Anadolu, $\mathrm{n}=70$ and Sultansuyu, $n=99$ ) and they were analyzed using DNA-PKcs gene specific polymerase chain reaction and fragment analysis by capillary electrophoresis. The result of the study showed that, none of the examined Arabian horses has SCID mutation on their responsible gene region. In conclusion, no SCID carrier was identified among examined stud Arabian horses that were representing the $65.5 \%$ (239 out of 365 ) of all officially registered stud animals in Turkey. It is believed that, this first genetic screening study focused on the SCID determination at national level and the evidence of the disease absence have the potential to increase breeding value of Arabian horses originated from Turkey.
\end{abstract}

Key words: DNA-PKcs, hereditary disorder, SCID, Turkish Arabian horses.

\section{Türkiye devlet çiftliklerindeki damızlık Arap atlarında şiddetli kombine immun yetmezliği (SCID) hastalığının araştırılması}

Özet: Arap atlarında görülen Şiddetli Kombine İmmun Yetmezliği (Severe Combined Immunodeficiency, SCID), ölümcül ve otozomal çekinik aktarılan kalıtsal bir hastalıktır. SCID’in atlardaki genetik temeli DNA-bağımlı protein kinazın katalitik alt ünitesi geninde (DNA-PKcs) 5 baz çiftlik bir delesyondur. Şimdiye kadar, Türkiye'de yetiştirilen Arap atlarında SCID varlığı hakkında klinik gözlem ve moleküler tanı açısından bilgi bulunmamaktadır. Bu çalışmanın başlıca amacı; moleküler teknikler kullanarak SCID mutant alleli taşıyıcılarının varlığının araştırılması ve SCID sıklığının belirlenmesidir. Çalışmada devlet çiftliklerinde yetiştirilen 239 baş Arap atından DNA (Karacabey $n=70$; Anadolu $n=70$ ve Sultansuyu n=99) elde edilmiş ve DNA-PKcs genine özgü polimeraz zincir reaksiyonu ve fragment analizi kullanılarak analiz yapılmıştır. Çalışma sonucunda, incelenen Arap atlarının ilgili gen bölgesinde SCID mutasyonu taşımadıklarını gösterilmiştir. Sonuç olarak, Türkiye'de devlet eliyle yetiştirilen damızlık Arap atlarının toplam sayısının \%65.5'inde (365 baş Arap atının 239'unda) SCID taşıyıcısı belirlenmemiştir. Türkiye'de ulusal düzeyde SCID genetik tanısına yönelik gerçekleştirilen bu ilk çalışmayla birlikte hastalığın bulunmadığına dair ortaya konulan bulguların, Türkiye'de yetiştirilen Arap atlarının değerini arttırma potansiyeline sahip olduğu düşünülmektedir.

Anahtar sözcükler: DNA-PKcs, kalıtsal hastalık, SCID, Türkiye Arap atları.

\section{Introduction}

Severe Combined Immunodeficiency (SCID) is a well-known genetic disorder reported only in Arabian horses and crossbreeds, dogs, mice and humans $(7,10$, 13, 20). The animals having mutant SCID genotype show $\mathrm{T}$ and $\mathrm{B}$ lymphocyte depletion in their bone marrows, lymph nodes and spleen (13). They generally die after a short period of non-specific secondary infections coassociated with cellular and humoral immunodeficiency $(1,4,8,19)$. The genetic basis of equine SCID is the deletion of 5 base pairs (TCTCA) beginning with codon 9480 in the DNA-protein kinase catalytic subunit (DNAPKcs) in the short arm of chromosome 9 (ECA9p12) (2, $16,25)$. This mutation causes a frame-shift mutation and premature termination and results in a deletion of 967 amino acids that include the phosphatidylinositol 3kinase (PI3-kinase) region on the C-terminal and therefore an inactive DNA-PKcs protein $(13,16)$. DNAPKcs is a factor in DNA repair process and it is an essential protein for non-homologous DNA end joining 
(NHEJ) $(16,18)$. Therefore, the absence of this protein leads to errors in $\mathrm{V}(\mathrm{D}) \mathrm{J}$ recombination and prevents the development of the antigen-specific immune response by causing a deficiency in differentiation and maturity of lymphocytes (25). As a result, affected foals become extremely sensitive to secondary opportunistic infectious agents; Equine adenovirus, Pneumocystis carinii, Cryptosporidium parvum, and Rhodococcus equi. Most of the affected foals with severe immunodeficiency generally die before they reached to their six months of ages. Thus, SCID is one of the most frequent causes of Arabian foal deaths, which are unresponsive to the antimicrobial treatment $(1,4,8,9,19)$. It also means that, even though all-infectious etiologies lying under the clinical course are treated, SCID maintains tremendous immunodeficiency in those foals. Therefore, they may die after an opportunistic infection originating from microorganisms normally found on the mucosa of healthy immunocompetent animals.

When the performances of Arabian racehorses raised in Turkey, Russia, the United States of America (USA) and Qatar are compared, Turkish Arabian horses place well in the world rankings (24). However, there is no research investigating hereditary diseases in horses raised in Turkey, and even there is still insufficient data regarding screening, control and possible impacts on international trade of such genetic disorders. In developed countries (USA, Australia, Canada, England, etc.), routine DNA tests that provide accredited results in quite short time, are used for identification of hereditary diseases at professional horse-breeding facilities $(5,26)$. As a result, horses with hereditary diseases are removed from the breeding program, thus ensuring that these genetic faults are not transferred through the new generations. Severe combined immunodeficiency is one of the most important hereditary diseases in horses. The first equine SCID cases were reported in 5 to 8-monthsold 29 Arabian foals, had limited resistance to infections (10). Later, similar immunodeficiency syndromes were also described by several researchers in Arabian horses from different geographic regions $(6,9,23)$. Studies indicated that the immunodeficiency observed in these foals was caused by lymphopenia, hypogammaglobulinaemia, the failure of germinal centers to form in lymphoid organs $(7,10,12,13,25)$. The findings described in these studies were only reported in Arabian horses and exhibited autosomal recessive genetic disorder $(5,12)$. SCID can be diagnosed by looking for the presence of characteristic laboratory and clinical findings, as is the case with numerous hereditary diseases. However, the clinical findings that emerge with SCID are not always sufficient for a definitive diagnosis, and heterozygous animals do not exhibit clinical findings (13).
Arabian horse breeding, in addition to its former military significance, is still economically and socially important for Turkey. For this reason, stud breeding and horse sales have mainly been carried out by the state since the times of the Ottoman Empire. To date, SCID has never been identified by clinical diagnosis in Turkish Arabian horses, and the purpose of this study was to use molecular techniques to see if it was present and if so, the incidence of carriers.

\section{Materials and Methods}

Animal material: In this study, stud Arabian horses kept in three state farms in Turkey, Anadolu, Karacabey and Sultansuyu facilities of the Ministry of Agriculture, were visited between 2009 and 2010. At those farms, the blood samples were collected from 239 out of 365 clinically healthy Arabian horses by using intravenous catheter into vacutainer tubes containing $\mathrm{K}_{3}$ EDTA. During the selection procedure of the animals, at least 3 years residence was taken into account in those stud farms. The information on total horse population and sampled animals ratio in each farm was given in Table 1. The mean ages of the horses included in the study was calculated as $10 \pm 5.7$ (minimum: 3, maximum: 22 ) using official data given by Ministry of Food, Agriculture and Livestock, Turkey (http://www.tigem.gov.tr/isletmeler). Distribution of the examined horses among different age groups was also given in Figure 1. All the examined horses and their parents are indigenous, except imported animals from Poland $(n=3)$ and USA $(n=9)$.

Table 1. Sampling percentage of the examined animals in state stud farms.

Tablo 1. Damızlık Arap atı çiftliklerinde incelenen hayvanlara ait örnekleme oranları.

\begin{tabular}{lccc}
\hline State farm & $\begin{array}{c}\text { Total numbers } \\
\text { of studs }\end{array}$ & $\begin{array}{c}\text { Sampled Studs } \\
\text { Number }\end{array}$ & $\begin{array}{c}\text { Percentage of } \\
\text { sample size (\%) }\end{array}$ \\
\hline Anadolu & 109 & 70 & 64.2 \\
Karacabey & 152 & 70 & 46 \\
Sultansuyu & 104 & 99 & 95.2 \\
Total & 365 & 239 & 65.5 \\
\hline
\end{tabular}

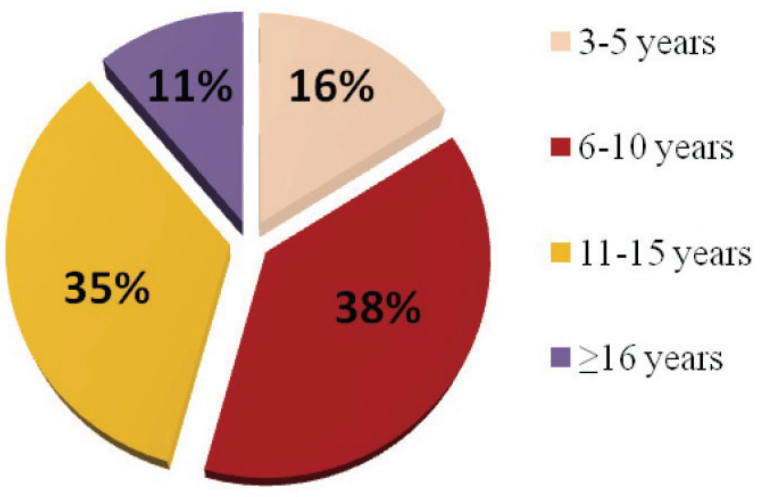

Figure 1. Population structure by major age groups. Şekil 1. Başlıca yaş gruplarına göre populasyon yapısı. 
Total DNA isolation: DNA extractions from whole blood samples were performed using the spin-column based commercial kits (DNeasy Blood\&TissueKit, Qiagen GmbH, Hilden, Germany). DNA was quantified by spectrophotometry at wavelengths of $260 \mathrm{~nm}$ and 280nm.

PCR and fragment analysis: PCR analysis was conducted in compliance with the method proposed by Swinburne et al. (20). PCR was performed in a $25 \mu \mathrm{l}$ reaction mixture containing 100ng of genomic DNA, $3 \mathrm{mM} \mathrm{MgCl} 2$, $5 \mathrm{pmol}$ of each primer, $200 \mu \mathrm{M}$ of each dNTP, 1U Taq DNA polymerase and 1X PCR buffer (10mM Tris- $\mathrm{HCl}, \mathrm{pH} 9.0 ; 50 \mathrm{mM} \mathrm{KCl}$ ), using the Mastercycler thermal cycler (Eppendorf AG) under the following conditions: First denaturation for $4 \mathrm{~min}$ at $94^{\circ} \mathrm{C}$ followed by 30 cycles of $30 \mathrm{sec}$ denaturation at $94^{\circ} \mathrm{C}$, $30 \mathrm{sec}$ primer annealing at $62^{\circ} \mathrm{C}$ and $70 \mathrm{sec}$ extension at $72{ }^{\circ} \mathrm{C}$ with a final extension of $15 \mathrm{~min}$ at $70^{\circ} \mathrm{C}$. Forward and reverse primer sequences were $5^{\prime}$ AAG TTG GTC TTG TCA TTG AGC-3' and 5'- TTT GTG ATG ATG TCA TCC CAG -3', respectively, and would yield a product $163 \mathrm{bp}$ in length. Electrophoresis of amplicons was conducted for $30 \mathrm{~min}$ at $120 \mathrm{~V}$ in $4 \%$ agarose gel (NuSieve GTG, Lonza) containing ethidium bromide, which the manufacturer describes as providing resolution up to two bp. The size of the PCR product was confirmed by using DNA molecular size standards under UV-light. Controls were included in each set of PCR amplifications of suspected sample DNA. A negative control lacking DNA template as well as a positive control containing DNA extracted from a SCID heterozygous individual were used. For fragment analysis and capillary electrophoresis, which allow more sensitive base resolution, the forward primer was also labeled with WellRED D4 dye (Sigma, Proligo, St. Louis, MO) and loaded into the CEQ 8000 DNA Fragment Analyzer (Beckman Coulter Inc.) using a CEQ 400 bp DNA size standard (Beckman Coulter Inc., Cat no 608098). In healthy individuals, it was thought that the amplified region would yield 163 base fragments (wild allele), while the individuals carrying the allele with the 5-base deletion would yield 158 base fragments (mutant allele).

\section{Results}

In the study, a single-type banding pattern was observed in all of the samples on agarose gel electrophoresis following PCR amplification. This image was identified as an expression of a wild kind of homozygous genotype. However, in order to test the possibility of a false negative result caused by the resolution of agarose gel electrophoresis, fragment analysis was conducted in capillary electrophoresis by means of the labeled forward primer. All of the samples were again amplified with the labeled primer in accordance with the fragment analysis. Figure 2 shows the heterozygous DNA fragment peaks for the amplified region of positive control sample. The homozygous peak was observed above 163 base pairs that were accredited as wild allele in all samples. On the other hand, the heterozygous band pattern carrying the mutant allele (158bp) was not observed in any of the samples, and so no carriers were identified in the Turkish population of Arabian horses in the state studs. The results of the fragment analysis for all of the animals were recorded and reported to General Directorate of Agricultural Enterprises (TIGEM).

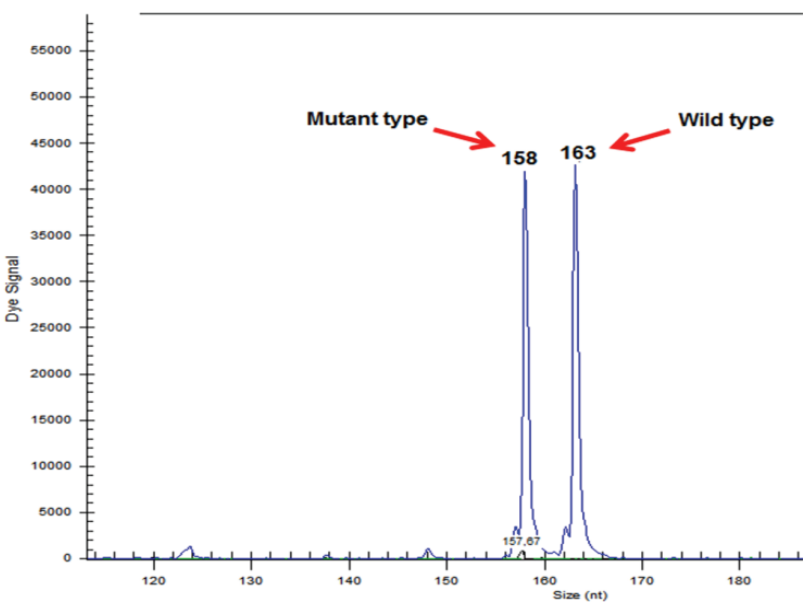

Figure 2. Representation of the heterozygous DNA fragment peaks.

Şekil 2. Heterozigot DNA fragment piklerinin gösterimi.

\section{Discussion and Conclusion}

Severe combined immunodeficiency is a genetic disorder and it can be transmitted throughout the next generations of stud horses carrying its causative mutant alleles (25). However, while heterozygous Arabian horses appear healthy, homozygous newborn foals often die consequent to challenge with enormous viral, bacterial and parasitary complications (1, 4, 8, 9, 19). Therefore, stud Arabian horses using in the breeding programs, do not show any clinical signs of SCID and the disease can be overlooked. This silent and subclinical feature of the SCID may cause a tremendous increase in the incidence where the stud horses were not tested genetically.

After development of reliable and useful DNAbased tests, contemporary incidence values of SCID carrier and clinically affected foals have been increasingly reported from different countries $(3,11,14$, $21,20,22,26)$. For example, it is reported that 17 of 204 (8.3\%) foals are found SCID affected in Australia (11). 
Otherwise, expected ratio of affected foals has been estimated as low as $0.18 \%$ in USA (3). The frequencies of the SCID carriers were reported $8.4 \%$ in USA (3), $7 \%$ in Morocco (14), $1.5 \%$ in Brazil (21) and $2.8 \%$ in the United Kingdom (20). No carriers have been identified in tested 271 and 106 Arabian horses of Poland and Slovenia, respectively $(22,26)$. Poppie and McGuire (15) estimated that the $25.7 \%$ frequency in heterozygous carrier animals by the aid of $2.3 \%$ SCID incidence in USA. The high levels of the percentages of carriers suggest that in some countries inbreeding is highly being practiced. Nevertheless, in order to interpret these percentages, one would have to take into consideration which countries exported breeding animals to the other and the incidence of the disease in these countries.

Various methods are used to determine heterozygosis in SCID. These include polymerase chain reaction analysis $(3,14,26)$, polymerase chain reaction followed by southern hybridization analysis (17) and fragment and sequence analysis based on capillary electrophoresis (20). In this study, PCR followed by high-resolution agarose gel electrophoresis was chosen because of its user-friendly application and economical advantage (26). However, as agarose gel technique has weakness on the differentiation of homozygous and heterozygous individuals, then accuracy of the analysis is also confirmed by fragment analysis by capillary electrophoresis in this study.

In the present study, no SCID carrier was identified with PCR analysis and fragment analysis of examined 239 Arabian horses. Although nine of them were exported from USA, which has high-level of SCID carriers, they were also found homozygous wild type (3). In Turkey, Arabian stud horses are mostly raised at the state stud farms and the total number of registered stud horses is 365 according to TIGEM official records. Thus, in this study the great majority of those stud horses $(65.5 \%, 239$ out of 365$)$ were screened for SCID.

In conclusion; considering the age groups and hence the birth years of the examined horses, the present study, put forward to consideration about stud horses born between from 1987 to 2006 years in the state stud farms. In this regard, a contribution has been made to contemporary literature by demonstrating the current situation regarding SCID carriers in state stud farms in Turkey. This conclusion enhances the breeding value of Turkish Arabian horses. Nonetheless, there is no information current situation and frequency of SCID in total Arabian horse population including all indigenous and imported Arabian horses in commercial stud farms and private breeding farms in Turkey. Consequently, in order to claim that this disease is entirely absent from the population, all of the stud farms and imported horses should also be examined in terms of SCID.

\section{Acknowledgements}

The authors would like to thank Dr. Samantha Brooks from Cornell University, Department of Animal Science, for the providing positive control DNA sample. This research was supported by Ankara University, the Office of Scientific Research Projects (Grant number 08B3338004).

\section{References}

1. Ainsworth DM, Weldon AD, Beck KA, Rowland PH (1993): Recognition of Pneumocystis carinii in foals with respiratory distress. Equine Vet J, 25, 103-108.

2. Bailey E, Reid RC, Skow LC, Mathiason K, Lear TL, McGuire TC (1997): Linkage of the gene for equine combined immunodeficiency disease to microsatellite markers HTG8 and HTG4; synteny and FISH mapping to ECA9. Anim Genet, 28, 268-273.

3. Bernoco D, Bailey E (1998): Frequency of the SCID gene among Arabian horses in the USA. Anim Genet, 29, 41-42.

4. Bjorneby JM, Leach DR, Perryman LE (1991): Persistent cryptosporidiosis in horses with severe combined immunodeficiency. Infect Immun, 59, 38233826.

5. Bowling AT, Ruvinsky A (2000): The Genetics of The Horse. CABI Publishing, UK, 146.

6. Clark EG, Turner AS, Boysen BG, Rouse BT (1978): Listeriosis in an Arabian foal with combined immunodeficiency. J Am Vet Med Assoc, 172, 363-366.

7. Felsburg PJ, Somberg RL, Perryman LE (1992): Domestic animal models of severe combined immunodeficiency: canine X-linked severe combined immunodeficiency and severe combined immunodeficiency in horses. Immunodef Rev, 3, 277-303.

8. Mair TS, Taylor FGR, Harbour DA, Pearson GR (1990): Concurrent Cryptosporidium and Coronavirus Infections in an Arabian Foal with Combined Immunodeficiency Syndrome. Vet Rec, 126, 127-130.

9. McChesney TC, England JJ, Rich LJ (1973): Adenoviral infections in foals. J Am Vet Med Assoc 162, 545-549.

10. McGuire TC, Poppie MJ (1973): Hypogammaglobulinemia and thymic hypoplasia in horses: a primary combined immunodeficiency disorders. Infect Immun, 8, 272-277.

11. Nicholas FW (1987): Veterinary Genetics. 1st edn. Oxford University Press, New York, 94-95.

12. Perryman LE, Torbeck LR (1980): Combined immunodeficiency of Arabian horses: confirmation of autosomal recessive mode of inheritance. $\mathrm{J}$ Am Vet Med Assoc, 176, 1250-1251.

13. Perryman LE (2004): Molecular pathology of severe combined immunodeficiency in mice, horses, and dogs. Vet Pathol, 41, 95-100.

14. Piro M, Benjouad A, Tligui NS, El Allali K, El Kohen M, Nabich A, Ouragh L (2008): Frequency of the severe combined immunodeficiency disease gene among horses in Morocco. Equine Vet Jour, 40, 590-591.

15. Poppie MJ, McGuire TC (1977): Combined immunodeficiency in foals of Arabian breeding: evaluation of mode of inheritance and estimation of prevalence of affected foals and carrier mares and stallions. J Am Vet Med Assoc, 170, 31-33. 
16. Shin EK, Perryman LE, Meek K (1997): A kinasenegative mutation of DNA-PK(CS) in equine SCID results in defective coding and signal joint formation. J Immunol, 158, 3565-3569.

17. Shin EK, Perryman LE, Meek K (1997): Evaluation of a test for identification of Arabian horses heterozygous for the severe combined immunodeficiency trait. J Am Vet Med Assoc, 211, 1268-1270.

18. Shin EK, Rijkers T, Pastink A, Meek K (2000): Analyses of TCRB rearrangements substantiate a profound deficit in recombination signal sequence joining in SCID foals: implications for the role of DNA-dependent protein kinase in $V(D) J$ recombination. J Immunol, 164, 14161424.

19. Snyder SP, England JJ, McChesney AE (1978): Cryptosporidiosis in immunodeficient Arabian foals. Vet Pathol, 15,12-17.

20. Swinburne J, Lockhart L, Scott M, Binns MM (1999): Estimation of the prevalence of severe combined immunodeficiency disease in UK Arab horses as determined by a DNA-based test. Vet Rec, 145, 22-23.

21. Teixeira CS, Oliveira DAA, Kuabara MY (2001): Prevalência da imunodeficiência severa combinada em cavalos da raça Árabe em plantéis de Minas Gerais e São Paulo Arq. Bras Med Vet Zootec, 53, 380-384 (article in portuguese with an English abstract).
22. Terry RR, Cholewinski G, Cothran EG (1999): Absence of the severe combined immunodeficiency disease gene among Arabian horses in Poland. J Appl Genet, 40, 39-41.

23. Thompson DB, Studdert MJ, Beilharz RG, Littlejohns IR (1975): Inheritance of a lethal immunodeficiency disease of Arabian foals. Aust Vet J, 51, 109-113.

24. Türkiye Jokey Klubü. Türk Arap atı soykütüğ̈̈ (Turkish Arabian Horse Studbook). 1st edn. Veliefendi Hipodromu Bakırköy, Istanbul, 1997.

25. Wiler R, Leber R, Moore BB, VanDyk LF, Perryman LE, Meek K (1995): Equine severe combined immunodeficiency: a defect in $V(D) J$ recombination and DNA-dependent protein kinase activity. Proc Natl Acad Sci, USA 92, 11485-11489.

26. Zavrtanik J, Mesarič M, Majdič G (2005): Genetic monitoring for Severe Combined Immunodeficiency carriers in horses in Slovenia. Slov Vet Res, 42, 37-41.

Geliş tarihi: 28.01.2013 / Kabul tarihi: 16.09.2013
Address for correspondence:
Assist. Prof. Dr. Bengi Çınar Kul
Department of Genetics,
Faculty of Veterinary Medicine
Ankara University, 06110, Diskapi,
Ankara-Turkey
e-mail:bkul@ankara.edu.tr 